\title{
Maximizing Stockholder Wealth under Corporate Governance Mechanisms: Evidence from EGX
}

\author{
Osama Wagdi ${ }^{1}$, Eman Salman ${ }^{2} \&$ Walid Abouzeid ${ }^{3}$ \\ ${ }^{1}$ Faculty of Economics and International Trade, Egyptian Chinese University, Cairo, Egypt \\ ${ }^{2}$ Faculty of Commerce and Business Administration, Helwan University, Cairo, Egypt \\ ${ }^{3}$ International Academy for Engineering and Media Science - IAEMS, 6th of October City, Egypt \\ Correspondence: Osama Wagdi, ORCID 0000-0003-0451-9726; ResearcherID: D-4898-2019; Scopus Author ID: \\ 57212470180; Faculty of Economics and International Trade, Egyptian Chinese University (ECU), Gesr El-Suez \\ st. behind Tagneed Bridge, Cairo, Egypt. E-mail: osamawagdi_ta@yahoo.com
}

Received: January 7, 2021

Accepted: February 19, 2021

Online Published: March 10, 2021

doi:10.5539/ijef.v13n4p1

URL: https://doi.org/10.5539/ijef.v13n4p1

\begin{abstract}
The study dealt the corporate governance mechanisms (CGM) to achieve the goal of maximizing stockholder wealth. That under the dividend decision is the crux of the agency problem. A quantitative sample of 15 companies listed on the Egyptian Stock Exchange for the period from 2005 to 2019. According to the quantitative analysis, the interpretation rate of corporate governance mechanisms is $60.97 \%$ of maximizing stockholder wealth in the Egyptian business environment. While the qualitative analysis included 417 individuals that have been examined according to a survey (questionnaire). The results concluded that there is a significant difference in the attitudes of stakeholders towards the role of CGM in determining dividend decision.
\end{abstract}

Keywords: corporate governance mechanisms, agency problem, dividend decision, cash dividend, stock dividend, retained earnings

JEL Classification: G19,G30, G35, O16.

\section{The Methodological Framework of Study}

\subsection{Introduce the Problem}

The return from investment operations in the stock market is represented in two types of return; namely the current return, which results from the cash dividend to shareholders. In addition to capital gains, the return resulting from the differences between the values of buying and selling those assets.

Both current returns and capital returns are functions of the dividend decision, as this decision is the direct determinant of the first - current returns - rather than the indirect determinant of the second - capital returns - in regards to the market's assessment of this decision of its ability to achieve the goal of maximizing the wealth of owners. By analyzing the effect of the dividend decision, whether cash or stock dividend, or buying treasury shares on each of the real assets (the reflection of the dividend decision on the financial position of the issuing establishment) instead of the financial assets (the performance of the issued shares in the trading market).

Under the struggle over the benefits and interest desired by each of the stakeholders, a part of governance's role is to rationalize the dividend decision according to the disparity between the benefits and interests of each of their parties of stakeholders. This is what makes the dividend decision a pivotal decision that includes the essence of the agency problem.

According to "Investments Cycle" as well as "Cash Flows between Capital Markets \& Corporate's Operations"; Cash generated from corporate's operations and returned to managers; the manger can direct cash reinvested in corporate's operations, named as retained earnings for reinvestment; or cash returned to investors (stockholder) named as cash dividend.

The agency problem arises through the trade-off between "dividend pattern and amount" on hand and "support a corporate's growth" under "the benefits and interest of manager vs. the benefits and interest of stockholders" on the other hand. Within meeting stockholders according to voting or during market transaction such as "selling and exit" or "building short positions" there is an impact of stockholders on managers, the case study deals with 
the last case.

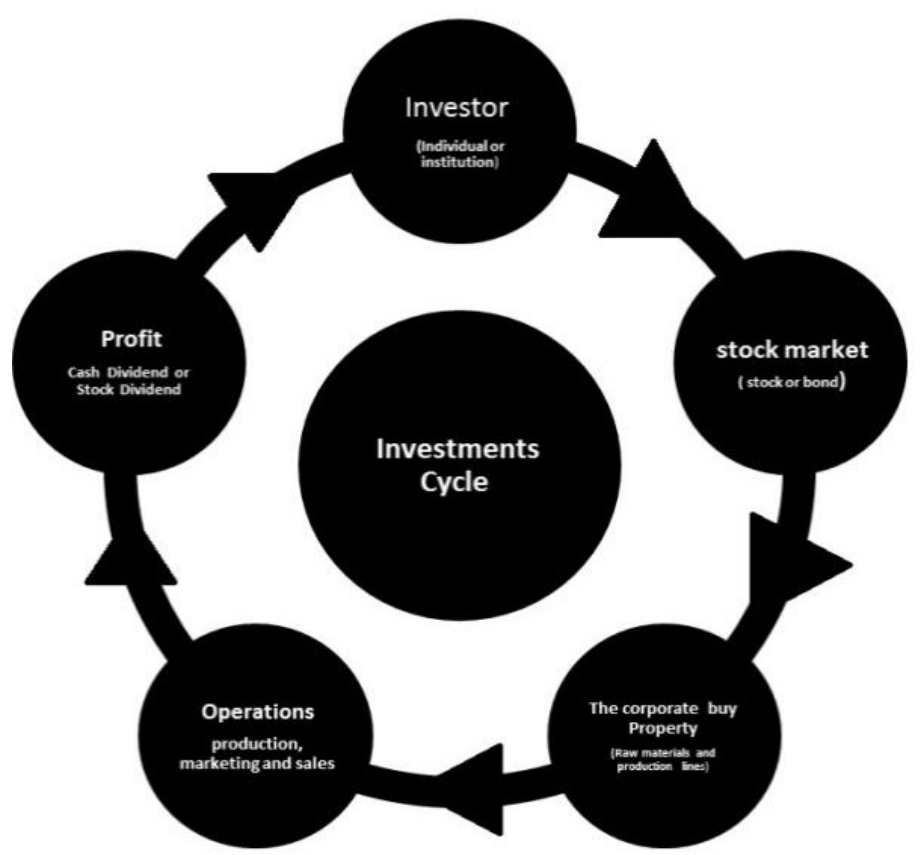

Figure 1. Investments cycle

Source: Authors.

\subsection{Literature Review}

In order to identify the research gap, the researchers reviewed many studies related to the dividend decision and the mechanisms of governance, as well as the most significant previous studies related to the research topic that can be classified into groups as follows:

\subsubsection{Studies Related to Dividend Decision}

Studies related to the dividend decision can be classified into three main sections as follows:

\subsubsection{Dividend Decision and Market Value}

Rozeff (1982) indicates that the dividend decision is related to the cost of the agency, which means that there is an optimal limit for dividend decision to reduce that cost, while Grinblatt et al. (1984) dealt with the effect of both dividends and the stock split on stock returns, the study concluded that they have an impact on stock returns, especially in regards to expectations of higher dividends while Dehghani and Chun (2011) which dealt with the impact of announcing extraordinary dividends on stock returns indicates that according to the study of the Malaysia Stock Exchange case, the study found a positive effect of that announcement on stock returns.

As for the most important methodologies used in previous studies that dealt with the dividend decision, the study indicates that the event methodology is the most likely aspect in this regard. Seiler (2000) indicates that the study of the event has become a basic approach to know and measure the impact of the event on stock returns. (Lack of effect).

In 1969; the methodology presented by Fama et al. through their study entitled "Adjustment of stock prices to new information" in the "International Economic Review" in the last quarter of the last century witnessed a great interest in this type. Of the methodologies for the purposes of analysis, measurement, testing (including: Binder, 1985; Ball, \& Torous, 1988; Corrado, 1989; Henderson, 1990; Boehmer et al., 1991; Eckbo, 1990; Berry et al., 1990; Salinger, 1991; Savickas, 2003; Aktas et al., 2007; Corrado, 2011; Kolari \& Pynnonen, 2011). In contrast, the study finds the use of correlation and multiple regression methods with different methodologies, especially when analyzing the determinants of dividend decisions (including: Adjaoud \& Be-Amar, 2010; Jiraporn et al., 2011; Subramaniam \& Devis, 2011)

\subsubsection{Determinants of Dividend Decision}

The study (Zeng, 2011) indicates the effect of ownership on the pattern of dividend decision in Canadian companies, where the study indicates a many of factors affecting dividend processes, represented in the level of 
homogeneity of ownership, size, risk, liquidity, growth, and profitability of companies, which is consistent with the results of the study (Grinstein \& Michaely, 2005) that was tested on American companies, as it indicates divergent trends in institutional ownership towards dividend policies.

As for family businesses, the study (Isakov \& Weisskopf, 2015) finds a difference in the pattern of dividends between family and non-family businesses. In addition, the study (Vandemaele \& Vancauteren, 2015) indicates the effect of the succession of generations in family firms on dividend decisions. There is a tendency to retain profits stronger in earlier generations' stages compared to later generations.

The study (Baker, \& De Ridder, 2018) indicates the effect of the sector type on the volatility of dividends, as this fluctuation increases in the financial services sector compared to the decline in the industrial sector companies.

As for the growth of the enterprise, the study (Dempsey et al., 2019) indicates the intellectual basis for the role of the company's growth stages according to the Boston Consulting Group (BCG) matrix on dividend policies. Companies with high dividends tend to have a low growth state, as opposed to companies with low dividends which tend to be in a state of high growth. It indicates that the market has difficulties distinguishing these types of companies.

As for the impact of the structure of operational costs on dividend policies, the study (Kulchania, 2016) indicates that companies whose operational commission structure is characterized by a high relative weight of fixed costs tend to buy treasury shares as an approach to distribute profits as an alternative to cash dividends, thus concluding (Kulchania, 2016) to firms' cost structures play a significant role in dividend policy choices.

This is aligned with the results of the study (Kim \& Ettredge, 1992) regarding cost estimation methods such as the methodology of inventory evaluation on the dividend of profits in companies in regards to the direct impact on both profitability and cash flows on the part of the management effect (what is known as profit management).

In contrast, the study (Wu et al., 2008) indicates the effect of executives' options on dividend processes, as the study concluded that when executives have, stock options, they may prefer to distribute cash dividends to enhance the share price.

\subsubsection{Studies Related to Governance}

Some studies have dealt with the role of governance mechanisms in light of economic crises, including the study (Anderson \& Campbell, 2004) which dealt with the relationship between governance mechanisms and financial performance before and after the crisis of Asian countries in the 1990s indicated that external governance mechanisms were not effective even until after the crisis, there were few instances of mergers and other changes in ownership and control, while internal governance mechanisms were more effective than in the pre-crisis periods.

\subsubsection{Studies Related to Governance Mechanisms and Dividends}

The study (Gugler, 2003) indicates the effect of the ownership structure on the dividend decision in companies that have investment opportunities for growth. It also indicates the divergence of dividends between the establishments with government control from the establishments with family control, while the study (Farinha, 2003) indicates that the positive impact of dividend decisions, especially in regards to the ownership of internal parties such as managers, which exceed the cutoff point at the level of $30 \%$, and this is seen as a mechanism to reduce the problem of agency, and thus the current study finds that there is an effect of the ownership structure mechanism as one of the governance mechanisms on the dividend decision.

As for the impact of the Board of Directors and the Audit Committee, the study (Elmagrhi et al., 2017) indicates the impact of each of the size of the board, board meetings, gender diversity and the size of the audit committee on the level of dividends in small and medium companies in the United Kingdom, or in emerging markets. (Mehdi et al., 2017) indicates that the dividend of profits is directly related to both the institutional ownership and the activity of the board of directors, in addition to the impact of governance mechanisms more broadly on decisions to distribute profits in light of crises according to the level of independence of the members of the board of directors beside the separation between the manager the executive (managing director) and the chairman of the board, thus the current study finds that there is an effect of the board of directors as one of the governance mechanisms on the dividend decision.

As for the external audit, there is a study that indicates that there is a reflection of the quality of the audit processes on the cash dividends of the Egyptian industrial companies in light of the quality level of profits.

The previous results are aligned with the results of the study (Mitton, 2004), which concluded that there is a positive relationship between the strength of governance mechanisms and cash dividends conditional on the rise 
in the legal protection for investors in the business environment of the issuing establishment, that is, there is an integrative relationship between the governance mechanisms and the legal protection for investors, and thus the study finds there is currently an impact of the supervisory authorities as one of the governance mechanisms on the dividend decision. These results are consistent with the results of studies (Adjaoud \& Ben-Amar, 2010) that concluded that Canadian companies have effective application of governance which is characterized by high cash distributions taking into consideration the size factor of the issuing facility (a control variable), rather than the effect on risk, in addition to the results of a study (Jiraporn et al., 2011), which concluded that American companies with a high level of application of corporate governance tend to prefer cash distribution to a great extent. These distributions are high compared to other companies; as effective governance mechanisms work to reduce the practices of opportunistic managers towards avoiding the distribution of profits.

As for the studies that dealt with the Arab business environment, we find studies that concluded that there is a relationship between the characteristics of the board of directors and the audit committees on the rate of cash distributions in the Egyptian joint-stock industrial companies, and that the characteristics of the board of directors had the most significant effect on the rate of cash dividends compared to the effect of Audit committees on the rate of cash dividends in the Egyptian joint stock industrial companies.

\subsubsection{Comments}

In regards to the previous studies, the two researchers conclude the following points:

1) There is a correlation between the dividend decision on one side and the agency cost on the other side (Rozeff, 1982). Regarding the use of governance mechanisms to reduce these type of costs, researchers can expect to rationalize the governance mechanisms for the decision to distribute profits, including bringing the agency's costs to a minimum which maximizes stockholders' wealth.

2) The results of previous studies broadly indicate the effect of the ownership structure on the dividend decision, which is evident in the institutional ownership pattern (Grinstein \& Michaely, 2005) and the family ownership pattern (Isakov \& Weisskopf, 2015).

3) The results of previous studies indicate the reflection of the effectiveness of some governance mechanisms on the dividend decision in regards to the quality of the financial statements, which is done through some governance mechanisms such as the audit committee and the external audit, in addition to the above, the researchers expect that the internal audit mechanism also has an impact on the quality of the financial statements.

4) There are factors governing the implications of governance mechanisms on the performance of the issuing firms and their decisions including the size of the issuing enterprise, the degree of leverage (debt use) and the characteristics of the business environment, which leads to a variation in the impact of governance mechanisms on the dividend decision in the exporting firms.

According to the above it is evident that a new research area - within the limits of the researchers 'knowledge - is foreseen, which is the dividend decision in light of the mechanisms of corporate governance to achieve the goal of maximizing the wealth of owners of the listed establishments whose shares are traded on the Egyptian Stock Exchange, as Arab academic research did not address it instead of the fact that most foreign studies have been limited to the effect of the mechanisms of governance over the dividend decision without concern for the purpose of maximizing stockholder wealth.

\subsection{Research Problem}

The goal of Maximizing Stockholder Wealth is one of the main goals agreed upon, but more than that, this goal is taken as an acceptable goal for both managers and shareholders, but this acceptance is unrealistic, except in one case only, which is that managers are the owners (shareholders). Although managers are agents of shareholders, this discrepancy generates the agency problem. This leads to managers' reluctance to achieve the goal of maximizing stockholders' wealth due to their influence by other factors when making their decisions within business establishments, including the divergent interests and informational asymmetry between managers and shareholders, which gives up the problem of management's avoidance of risk and the problem of the over retention problem.

Thus, there are several deficiencies that the financial markets suffer from with regard to the dividend of corporate profits of all kinds (Cash Dividend and Stock Dividend, and there are some that are added to them by the purchase of Treasury Stock), which is reflected in the market value of shares in the trading market with regards to the evaluations of those decisions made by shareholders, which requires rationalizing the dividend decision - which represents the benefits resulting from holding shares and whose fair value is determined due to the shareholders' preferences towards risk by estimating their current value and growth rate - which is not the 
case. It is only achieved through governance mechanisms, where effective governance mechanisms reduce the practices of opportunistic managers towards avoiding the dividend of profits (Jiraporn et al., 2011) which limits the agency cost, as these costs are inversely related to the goal of maximizing stockholder wealth, according to the above, the research problem can be summarized in the following question:

Is there an impact of governance mechanisms on the effectiveness of the dividend decision to achieve the goal of maximizing stockholder wealth?

\subsection{Study Hypotheses}

Considering the research gap that has been identified through reviewing and analyzing previous studies as well as the research problem, the study hypotheses can be formulated as follows:

$\mathbf{H}_{1}$ : There is no significant impact of the governance mechanisms on achieving the goal of maximizing stockholder wealth.

$\mathbf{H}_{2}$ : There is no significant difference in the attitudes of stakeholders towards the role of the Board of Directors in determining the pattern of dividend decision.

$\mathbf{H}_{3}$ : There is no significant difference in the attitudes of stakeholders towards the role of a Shareholders Structure in determining of dividend decision.

$\mathbf{H}_{4}$ : There is no significant difference in the attitudes of stakeholders towards the internal audit role in the determination of dividend decision.

$\mathbf{H}_{5}$ : There is no significant difference in the attitudes of stakeholders towards the role of an audit committee in determining of dividend decision.

$\mathbf{H}_{6}$ : There is no significant difference in the attitudes of stakeholders towards the external audit role in determining of dividend decision.

$\mathbf{H}_{7}$ : There is no significant difference in the attitudes of stakeholders towards the role of the Regulatory and supervisory authorities in determining of dividend decision.

\subsection{Study's Methodology}

The study relies on the inductive and deductive approaches. The inductive approach is defined as the process of observing phenomena and collecting data on them to arrive at general principles and holistic relationships, which is the matter that the study presented by revealing relationships that did not refer to any of the previous studies which indicates the originality of the idea. This is through the descriptive analytical approach under using quantitative and qualitative analysis

\subsection{Sources of Data Collection}

The study is based on both quantitative (documentary survey) and qualitative (measuring attitudes) methods, as the first includes the companies listed in the Egyptian Stock Exchange (the Sources of data: the Egyptian Stock Exchange, Financial Regulatory Authority-Egypt, the Central Bank of Egypt) while the second includes the relevant individuals from the stakeholders of this companies (such as: shareholders/management/staff/creditors) to determine their attitudes towards the study problem.

\subsection{Study Structure}

The research structure can be summarized as follows:

1) The Methodological Framework of study.

2) The Framework for Corporate Governance.

3) Dividend decision under governance mechanisms.

4) Data Analysis and Hypotheses Testing.

5) Conclusions and Recommendations.

\section{The Framework for Corporate Governance}

\subsection{Introduction}

The goal of the enterprise has evolved from the goal of maximizing sales as this goal is not comprehensive, since the enterprise may increase its sales, but costs may also be high, so the goal of profit maximization has been moved. However, this goal is not optimal as it does not take into account the element of risk. Because profits may increase at the same time the risks increase, but maximizing stockholders' wealth has also become the ideal 
goal as it is concerned with many determinants including cash flows, long-term growth, timing of return, and the risk component.

In order to achieve the goal of maximizing stockholders' wealth, establishments usually take many decisions, which can be categorized into investment decisions versus financing decisions. Here lies the essence of creating value for ordinary shareholders through a trade-off between the internal rate of return (IRR) and the required rate of return. Rate of Return, which is one of the engines of value and growth for enterprises, which requires guiding this barter, and ends with a number of alternatives, such as reinvesting the profits generated from the project, or distributing profits or part thereof to the ordinary shareholders on the one hand, or borrowing to finance investment activities or operational, according to the circumstances, which highlights the problem of the agency.

Corporate governance is one of the most prominent and important issues in regional and international establishments, institutions and organizations. Interest in this topic has grown in many advanced and emerging economies over the past years, especially after a series of different financial crises that occurred in many companies that were triggered by financial corruption, mismanagement and their lack of control, experience $\&$ skills, in addition to the lack of transparency, as these crises and collapses caused many shareholders to incur heavy material losses, which prompted many investors to search for companies that implement the concept of corporate governance (Ayuso et al., 2014).

\subsection{Agency Problem}

Considering the developments of the business environment, especially in the previous century and the resulting expansion of business establishments, where it is no longer possible for the same person or persons to assume the tasks of ownership and management together, what is known as the separation of ownership from management has occurred, for this new situation; an attempt to control the problems stemming from this chapter considering the conflict over the benefits generated for each of the stakeholders. Thus governance emerged to reduce the level of conflict over those benefits. (Eisenhardt, 1989) (Hart, 1995) (Sheilfer \& Vinshy, 1997) (Seal, 2006) (Chen \& Sougiannis, 2012)

\subsection{The Concept of Governance}

There have been many definitions of corporate governance due to the general nature of this concept and its connection to many areas on one hand and the different cultural trends and intellectual backgrounds of those interested in it on the other hand. The trends of these definitions can be classified into three groups, the first concerned with directing and controlling the performance of companies, which focuses on the correlation of corporate governance. With regard to corporate issues of directing and monitoring performance (Code, 1992) (Kambil et al., 2006), the second group is concerned with identifying the parties related to corporate governance and clarifying the duties, responsibilities and powers granted to them (Demb \& Neubauer, 1992). Finally, the third group. It deals with the objectives of corporate governance and its importance to shareholders and other stakeholders (Shleifer \& Vishny, 1997) (OECD, 2004).

In this regard, the researchers prefer the second and third directions rather than the first direction in defining the concept of governance as the rules, laws and standards that define the relationship of stakeholders with the facility. In other words, governance works to regulate the relationships, rights and powers between each of the management of the facility on one hand and the shareholders campaign Bonds, workers, suppliers, creditors, and consumers, on the other hand.

That is, governance is working to provide answers to many questions including: How can stockholders ensure that management does not misuse their money? How can they ensure that management is working to increase the market value of common stocks and ensure their long-term profitability and growth? How much does the administration care about the basic interests of society in the context of sustainable development and environmental responsibility? Finally, how can shareholders and stakeholders effectively oversee management?

According to the previously mentioned it becomes clear that governance is not an end in itself as it seeks to improve the performance of enterprises in the business environment in which they operate, while obtaining sources of financing to achieve sustainable growth, in consideration of the aim of maximizing the wealth of stockholders without prejudice to the rights of any of the other stakeholders.

Achieving transparency and fairness, granting the right to hold the management accountable, achieving the protection of shareholders and workers, and limiting the exploitation of power in the public interest other than the enterprise. This will only happen through efficient and effective governance practices, as they govern the relationship between stakeholders in a range of fairness, objectivity and transparency. This strengthens and supports the feeling of reassurance for all parties, raises the level of confidence that the investor attaches to the 
facility, and is one of the most important factors that attract them to contribute to the securities it issues as the application of governance means evidence of confidence to invest in it.

\subsection{Governance Determinants}

Whether or not the good application of governance practices depends on the availability and quality of two sets of determinants, namely:

\subsubsection{External Determinants}

1) The general environment for investment in the country which includes laws regulating economic activity (including the laws governing the capital market and companies, regulation of competition, prohibition of monopolistic practices, bankruptcy and anti-corruption)

2) The efficiency of the banking or non-banking sector (securities markets / real estate finance / operational finance / securitization and others).

3) The degree of competitiveness of the markets, and the efficiency of the regulatory agencies and bodies in tightening control over all community organizations

4) Professional institutions (trade unions and associations of parties working in the business environment of auditors, accountants, lawyers, companies operating in the stock market, credit rating companies, financial and investment advice, etc.).

5) The efficiency and effectiveness of the judicial apparatus, which depends on the level of transparency and fairness and its ability to determine responsibility and prosecute the perpetrators of administrative and financial violations in quick and appropriate times.

The importance of external determinants is due to the fact that their presence guarantees the implementation of laws and rules that ensure proper management of facilities. In this regard, the researchers find that this is reflected in the business environment, especially with regard to the cost-specific and pricing efficiency.

\subsubsection{Internal Determinants}

1) Memorandum of Association: The Memorandum of Association represents the reservation of the ruling corner for the dividend and practices of the administrative authorities within the business establishments of what it determines from the legal framework in which they operate, in addition to organizing the administration within them.

2) The statute: These determinants serve to clarify the rules and foundations for decision-making and the dividend of powers within the facilities between the general assembly, the board of directors, and the executive directors, the availability of which on the one hand and their application on the other hand reduces the conflict between the interests of those parties. In this regard the researchers find that this also reflects on the minimization of the organizational struggle over benefits and resources. Thus, there is a difference in governance practices according to the different economic, legislative, political and social conditions of each country, and the nature of the relationship between stakeholders. Concentration of ownership in establishments, the identity of the controlling class of shareholders, the competence of the board of directors, the extent of legal protection for investors, the extent of capital market development, the market as one of the mechanisms for monitoring establishments.

\subsubsection{Determinants of Corporate Governance}

According to the previously mentioned, the researchers can identify determinants that differ in corporate governance practices as follows:

1) Characteristics of the issuing establishment

- The level of concentration of ownership and free circulation.

- Ownership pattern between institutional and individuals.

- The percentage of independent members of the Board of Directors.

- The relative strength of the formal and informal system (influence and organizational conflict).

- Effectiveness and efficiency of internal control systems (internal audit, audit committee).

- Management's attitudes toward earnings management.

2) Stock market characteristics (trading market)

- The efficiency of the stock market. 
- The depth of the stock market.

- The level of trading activity in the stock market.

3) Characteristics of the business environment

- The power of professional organizations.

- The extent of the rule of law and the legal environment.

- Political risks.

- $\quad$ Efficiency of banking and non-banking financial institutions.

\subsection{Governance Mechanisms}

Governance mechanisms are classified into internal and external mechanisms. According to the agency's entry, we can observe that internal governance mechanisms concerned with management behavior of the extent of deviation from the goal of maximizing wealth for shareholders while external mechanisms are concerned with monitoring facilities and market discipline, the researchers find long-term dynamic relationships between them.

\subsubsection{Board of Directors}

The board of directors is one of the mechanisms of internal governance, where the board is on the top of the organizational structure in the enterprise and has the highest authority. The board of directors is tasked with representing the interests of shareholders by determining the method of investing capital in a rational way (Van \& Levrau, 2004) with the aim of achieving the goal of maximizing the wealth of owners instead of the increasing importance of the board of directors in emerging economies where legal protection for investors is relatively weak, this importance increases according to asymmetry of information (Polsiri \& Wiwattanakantang, 2006).

The most important metrics that can be used to measure the effectiveness of the board of directors' mechanism as one of the governance mechanisms can be summarized through the following table 1 .

Table 1. Measures of effectiveness of the board of directors' mechanism as one of the mechanisms of governance

\begin{tabular}{|c|c|c|}
\hline Statement & Measurement method & $\begin{array}{l}\text { The effectiveness of the } \\
\text { mechanism }\end{array}$ \\
\hline $\begin{array}{l}\text { Separation between the } \\
\text { positions of the Chairman } \\
\text { and the Managing Director }\end{array}$ & $\begin{array}{l}\text { The formation of the Board of Directors includes the position of } \\
\text { Chairman of the Board of Directors (a non-executive position) and the } \\
\text { position of the Managing Director (an executive position) }\end{array}$ & Positive relationship \\
\hline Board size & $\begin{array}{l}\text { The number of members of the Board of Directors by the decision to } \\
\text { form the Board. }\end{array}$ & Positive relationship \\
\hline $\begin{array}{l}\text { Average representation of } \\
\text { independent members in } \\
\text { the Board of Directors }\end{array}$ & $\begin{array}{l}\text { The relative weight of the representation of independent (non-executive } \\
\text { - experienced) members in forming the board of directors. }\end{array}$ & Positive relationship \\
\hline $\begin{array}{l}\text { The Board of Directors } \\
\text { convenes }\end{array}$ & $\begin{array}{l}\text { The number of times the board of directors convened during the fiscal } \\
\text { year. }\end{array}$ & Positive relationship \\
\hline $\begin{array}{l}\text { Average representation of } \\
\text { board members at meetings }\end{array}$ & $\begin{array}{l}\text { The average weight of the relative representation of members of the } \\
\text { board of directors in meetings, whether independent or executive } \\
\text { members, during the fiscal year }\end{array}$ & Positive relationship \\
\hline $\begin{array}{l}\text { Average representation of } \\
\text { independent board } \\
\text { members at meetings }\end{array}$ & $\begin{array}{l}\text { The average weight of the relative representation of board members at } \\
\text { independent meetings during the fiscal year. }\end{array}$ & Positive relationship \\
\hline $\begin{array}{l}\text { Board decisions that are } \\
\text { made by (scrolling) }\end{array}$ & $\begin{array}{l}\text { The average weight of the relative decisions of the Board of Directors } \\
\text { to the total decisions made by scrolling during the fiscal year }\end{array}$ & Negative relationship \\
\hline $\begin{array}{l}\text { Ownership of management } \\
\text { executives }\end{array}$ & $\begin{array}{l}\text { The relative weight of the executive managers' ownership of the total } \\
\text { issued shares }\end{array}$ & Positive relationship \\
\hline $\begin{array}{l}\text { Stock options for } \\
\text { management executives }\end{array}$ & General Assembly Attitude & Positive relationship \\
\hline
\end{tabular}

Source: authors.

It is has been observed through documentary surveys of studies that dealt with the mechanism of the board of directors to the widespread use of both "separation between the positions of chairman and managing director" and the size of the board of directors "and" the rate of representation of independent members in the board of directors "as a measure of the effectiveness of the board of directors. 


\subsubsection{Internal Auditing}

Internal audit is one of the mechanisms of internal governance. The historical development of internal audit activities shows that it has moved from financial activity checks to operational activity checks. It has also moved from evaluating the performance of managing the activity to evaluating the economic value of the enterprise in terms of the effectiveness of investment and financing decisions in terms of and the extent of capacity in dealing with financial and business risks on the other hand in a dynamic business environment, rather than legislative changes in a number of international markets such as the United States of America as the requirements of Section 404 of the Sarbanes-Oxley Act.

Bodies and agencies regulating financial markets, in addition to the relevant professional bodies, have responded to these changes.

The COSO, Committee of the Treadway Committee of the American Society of Certified Public Accountants (AICPA) and the Institute of Internal Auditors (IIA) created an integrated framework for measuring and managing risks for the enterprise as a whole, which is known as Enterprise Risk Management (Hayne \& Free, 2014).

The most important metrics that can be used to measure the effectiveness of the internal audit mechanism as one of the governance mechanisms can be summarized through the following table 2 .

Table 2. Measures of effectiveness of the internal audit' mechanism as one of the mechanisms of governance

\begin{tabular}{|c|c|c|}
\hline Statement & Measurement method & $\begin{array}{l}\text { The effectiveness of the } \\
\text { mechanism }\end{array}$ \\
\hline $\begin{array}{l}\text { Professional opinion on fairness of } \\
\text { financial statements }\end{array}$ & $\begin{array}{l}\text { The type of professional opinion about the fairness of the financial } \\
\text { statements }\end{array}$ & Positive relationship \\
\hline $\begin{array}{l}\text { External audit notes on the } \\
\text { financial statements }\end{array}$ & The number of external audit notes on the financial statements & Negative relationship \\
\hline $\begin{array}{l}\text { An independent department for } \\
\text { internal audit processes. }\end{array}$ & The extent of an independent department for internal audit processes. & Positive relationship \\
\hline Internal audit processes & $\begin{array}{l}\text { The number of processes that were completed through the internal audit } \\
\text { during the fiscal year }\end{array}$ & Positive relationship \\
\hline Systems and plan for internal audit & $\begin{array}{l}\text { The existence of an internal audit system and a plan approved by the } \\
\text { Board of Directors Or a service provider providing internal audit } \\
\text { services from an external audit office }\end{array}$ & Positive relationship \\
\hline Internal audit report & Issuing and disclosing the internal audit report & Positive relationship \\
\hline $\begin{array}{l}\text { Presenting the internal audit } \\
\text { reports to the audit committee. }\end{array}$ & $\begin{array}{l}\text { The number of times the internal audit reports were presented to the } \\
\text { Audit Committee during the fiscal year }\end{array}$ & Positive relationship \\
\hline $\begin{array}{l}\text { Presenting internal audit reports to } \\
\text { the Board of Directors }\end{array}$ & $\begin{array}{l}\text { The number of times the internal audit reports were presented to the } \\
\text { Board of Directors during the fiscal year }\end{array}$ & Positive relationship \\
\hline
\end{tabular}

Source: authors

It is noted through documentary surveys of studies that dealt with internal audit that the use of a specific measure of the effectiveness of internal audit is not common.

\subsubsection{The Audit Committee}

The Audit Committee is considered one of the internal governance mechanisms, the precedence goes back to the Financial Market Committee in New York as the first interest in the Audit Committee (Ghali, 1998). This interest is due to its role in helping to ensure the preparation of financial reports in accordance with the applicable accounting standards in addition to its supervision of a job. Internal audit and its role in supporting the external audit function and increasing its independence, as well as its importance in emphasizing adherence to the principles of corporate governance. This contributes to increasing the level of confidence and transparency in the financial information that is disclosed, which led to the Corporate of financial exchanges to oblige the establishments that wish to Its shares are registered by establishing an audit committee (Walker, 2004).

The most important metrics that can be used to measure the effectiveness of the audit committee mechanism as one of the governance mechanisms can be summarized through the following table 3 . 
Table 3. Measures of effectiveness of the audit committee mechanism as a governance mechanism

\begin{tabular}{|c|c|c|}
\hline Statement & Measurement method & $\begin{array}{l}\text { The effectiveness } \\
\text { of the mechanism }\end{array}$ \\
\hline Presence of audit committee & uing the formation of the audit committee & Positive relationship \\
\hline The size of the audit committee & he number of members of the audit committee & Positive relationship \\
\hline dent members & $\begin{array}{l}\text { The relative weight of the representation of independent (non-executive - } \\
\text { experienced) members in forming the board of directors }\end{array}$ & elationship \\
\hline The & The number of times the audit committee convened during the fiscal year. & Posit \\
\hline $\begin{array}{l}\text { Average representation of audit } \\
\text { committee members in meetings }\end{array}$ & $\begin{array}{l}\text { The average ratio of the relative representation of the members of the audit } \\
\text { committee in the meetings, whether from independent or executive } \\
\text { members during the fiscal year }\end{array}$ & \\
\hline $\begin{array}{l}\text { and plan for the audit } \\
\text { ee }\end{array}$ & $\begin{array}{l}\text { nce of a system for the work of the audit committee and a plan } \\
\text { by the Board of Directors }\end{array}$ & elationship \\
\hline Audit committee processes & $\begin{array}{l}\text { The number of processes completed by the audit committee during the } \\
\text { fiscal year }\end{array}$ & Positive relationship \\
\hline Audit & Issuing and disclosing the audit committee report & Positiv \\
\hline $\begin{array}{l}\text { Presenting the audit committee } \\
\text { reports to the board of directors }\end{array}$ & $\begin{array}{l}\text { The number of times the audit committee reports were presented to the } \\
\text { board of directors during the fiscal year }\end{array}$ & Positive relationship \\
\hline
\end{tabular}

Source: authors.

\subsubsection{Ownership Structure}

The ownership structure is one of the mechanisms of internal governance. It represents one of the elements governing the extent to which shareholders can exercise their rights through the voting processes in the General Assembly. It is the direct control power over the management of the issuing enterprise. It is also worth noting here that small shareholders often think of sufficient experience to monitor and evaluate the work of the managers who have great caution over the flow of information, aside from a conflict of interests with major shareholders (Burlaka, 2005).

The most important metrics that can be used to measure the effectiveness of the ownership structure mechanism as one of the governance mechanisms can be summarized through the following table 4 .

Table 4. Measures of effectiveness of the ownership structure mechanism as a governance mechanism

\begin{tabular}{|c|c|c|}
\hline Statement & Measurement method & $\begin{array}{l}\text { The effectiveness of } \\
\text { the mechanism }\end{array}$ \\
\hline Institutional ownership rate & The relative weight of corporate ownership of the total issued shares. & Positive relationship \\
\hline Family ownership rate & The relative weight of family ownership out of the total issued shares. & Negative relationship \\
\hline $\begin{array}{l}\text { Representation rate of shareholders } \\
\text { in general assemblies. }\end{array}$ & $\begin{array}{l}\text { The relative weight of the shares represented in the general assemblies } \\
\text { (regular or irregular) out of the total issued shares }\end{array}$ & Positive relationship \\
\hline $\begin{array}{l}\text { Number of questions and inquiries } \\
\text { submitted by shareholders }\end{array}$ & $\begin{array}{l}\text { The number of questions and inquiries submitted by shareholders in the } \\
\text { general assemblies (regular or irregular) out of the total issued shares }\end{array}$ & Positive relationship \\
\hline
\end{tabular}

Source: authors.

It is noted through documentary surveys of studies that dealt with internal audit that the use of a specific measure of the effectiveness of internal audit is not common.

\subsubsection{External Audit}

The external audit is one of the mechanisms of external governance. In this regard, many studies and reports prepared in the wake of the financial collapses and crises resulting from the corruption and financial cases that many international companies have been exposed to such as Enron and WorldCom, have revealed the failure of preparing financial reports that express truly its financial performance. There are many issues that arouse interest and deserve discussion, perhaps the most prominent of which, as he put it, is the level of credibility enjoyed by audit offices, especially the quality of the professional standards on which they are based as well as the quality of the reports they prepare (Spivey, 2004). This highlights the role of the external audit in protecting the rights of interest groups.

The quality of auditing is a basic requirement for many market parties as the facilities management wants to impart confidence in their financial statements, rather than the desire of professional organizations to fulfill the audit profession with its responsibilities towards all related parties, so that the declared profits are of quality. The quality of profits means refers to the profits they declare. The company honestly expresses the real profits, that is, 
the published profits are of tangible existence in which there is no exaggeration, manipulation or probability figures (Bellovary et al., 2005).

The most important measures that can be used to analyze the effectiveness of the external audit mechanism as one of the governance mechanisms can be summarized through the following table 5 .

Table 5. Measures of effectiveness of the external audit mechanism as a governance mechanism

\begin{tabular}{llc}
\hline Statement & Measurement method & The effectiveness of the mechanism \\
\hline Multiple external auditors & The number of external auditors & Positive relationship \\
Journal of external auditors & The average period of the external audit contract & Positive relationship \\
The independence of the external auditor & $\begin{array}{l}\text { The external auditor does not provide other } \\
\text { services to the issuing establishment }\end{array}$ & Positive relationship \\
& & \\
\hline
\end{tabular}

Source: authors.

\subsubsection{Supervisory and Regulatory Authorities}

The supervisory and regulatory authorities are one of the mechanisms of external governance, in Egypt those authorities are represented in many governmental and professional bodies including the General Authority for Non-Banking Financial Supervision, the Central Bank of Egypt, the Ministry of Investment, the Investment Authority, the Ministry of Finance, the Corporate Authority, the Trade Union, the Bar Association etc.

The most significant measures that can be used to measure the effectiveness of the supervisory and regulatory authority mechanism as one of the governance mechanisms can be summarized through the following table 6 .

Table 6. Measures of effectiveness of the Supervisory and regulatory authorities as a governance mechanism

\begin{tabular}{lll}
\hline Statement & Measurement method & The effectiveness of the mechanism \\
\hline Attending general assemblies & Representation in general assembly meetings & Positive relationship \\
Monitoring trading operations & $\begin{array}{l}\text { The number of inquiries and stopping trading on } \\
\text { cases exceeding price limits }\end{array}$ & Positive relationship \\
\hline
\end{tabular}

Source: Authors.

\section{Dividend Decision under Governance Mechanisms}

\subsection{Introduction}

The significance of the dividend decision in its various forms (cash distribution, dividend of bonus shares, purchase of treasury shares) stems from the fact that it carries two important decisions which are the main axis in the value of the enterprise; namely the investment decision and the financing decision where the pattern and size of the dividend decision that the corporate adopts according to investment decisions and financing sources, as there is a dynamic relationship between them according to a comparison between internal sources of financing versus external sources according to the internal rates of return (IRR) and the weighted average cost of capital (WACC). Therefore, the rational management cannot take any decision in isolation.

Corporates make the dividend decision considering the net profits after taxes available to ordinary shareholders. This decision may not include cash dividend at all if the law permits this, or distributing all net profits after taking into account the minimum legal requirements, or Partial dividend decision between these two limits. Therefore, there is a conflict of theories according to tests for many of the dividend theories.

Table 7. Dividend decision theories

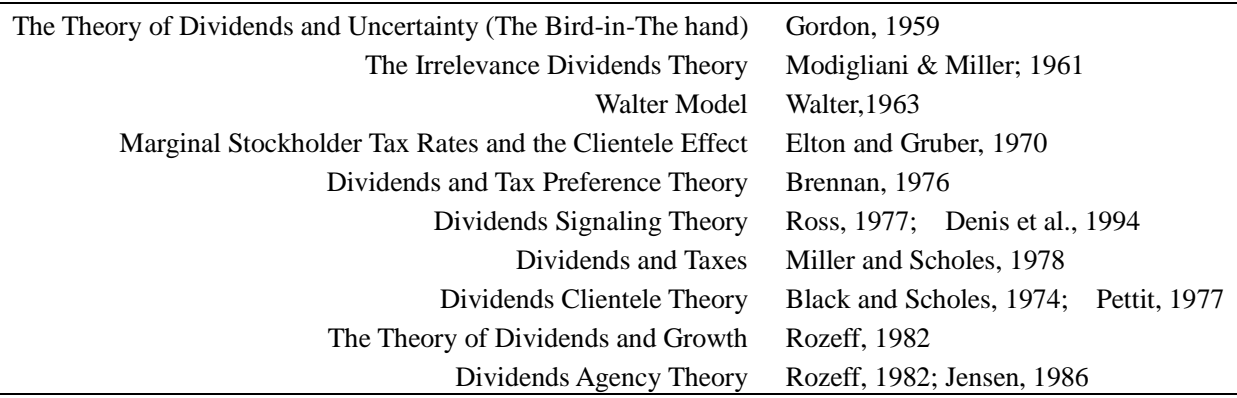

Source: Authors. 
There are many theories that analyze the dividend decision; these theories have assumptions and interpretations that may differ. However, there is one truth that the dividend decision can maximize Stockholder Wealth through comparison between the internal rates of return (IRR) and the weighted average cost of capital (WACC).

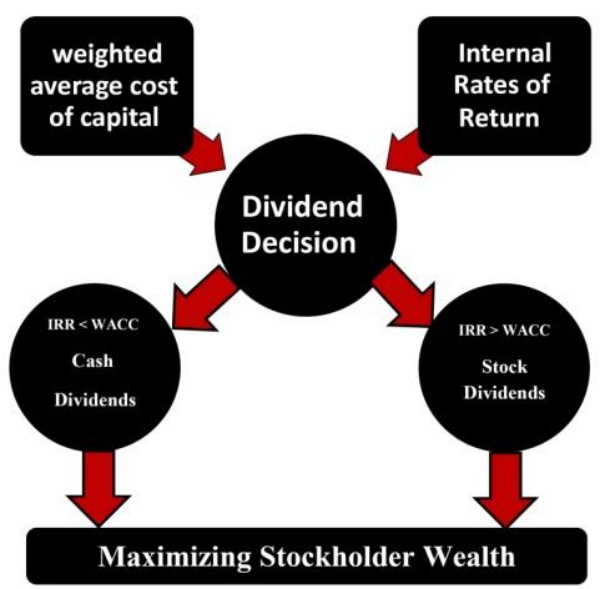

Figure 2. Maximizing stockholder wealth under dividend decision

\subsection{Determinants of Dividend Decision}

There is a set of determinants that affect dividend decisions whether in size or style which can be summarized as follows:

a. Legal considerations.

b. Liquidity levels.

c. Homogeneity of ownership.

d. The size of the establishment.

e. Risk levels.

f. Cost structure.

g. Type of sector.

h. The growth stage of the facility life cycle.

i. Stock owning options for Management.

The study will not cover all the previous determinants, however its efforts will focus on the determinants related to the research problem, as the call to distribute cash dividends to shareholders may face resistance on the part of managers, especially in medium and small-sized establishments where the management of these establishments find that under restrictions of the lack of benefit from economies of scale, and the direct and indirect effects that follow on the cost structure from one side and its reflection on the profitability structure.

On the other hand, the management of the corporate may be under the restrictions of the size of the corporate seeking to maximize its financial performance by retaining profits to develop its operational operations to take advantage of the possible savings from economies of scale. In contrast to the above, we find that when the management has stock options it may prefer to distribute cash dividends to enhance share price (Wu et al., 2008).

According to the foregoing, researchers can classify determinants that affect the dividend decision to include the size and pattern of this dividend decision into two groups: the first set of determinants related to the problem of agency which include: homogeneity of ownership, size of the enterprise, risk levels, cost structure, growth stage of the life cycle of the corporate management ownership options stocks and other determinants that are not related to the agency problem which include levels of liquidity, sector type and legal considerations.

\subsection{Governance Mechanisms and Dividend Decision}

There is an integration between the roles of the governance mechanisms in rationalizing the dividend decision whether it is (cash distribution, dividend of bonus shares, purchase of treasury shares), where the governance mechanisms start their role from the internal audit mechanism and then the audit committee. The main role of it 
is to ensure that the measurement and recognition processes are completed. According to the relevant professional principles (Egyptian accounting standards and international accounting standards, as the case), where the financial statements are prepared followed by reports that must fairly reflect the reality of the entity's financial performance, including the relevant financial or non-financial information.

The Board of Directors considers the third mechanism that deals with the reality of the financial performance of the establishment, which in turn resolves the financial statements to the external auditing processes. Thus the role of the external auditor appears as a fourth mechanism of government mechanisms that is concerned with expressing professional opinion in the extent of fairness and clarity of the financial statements. Finally, we find the mechanism of supervisory and regulatory authorities that it seeks to protect the rights of shareholders, especially the rights of the minority and thus show all the mechanisms of governance.

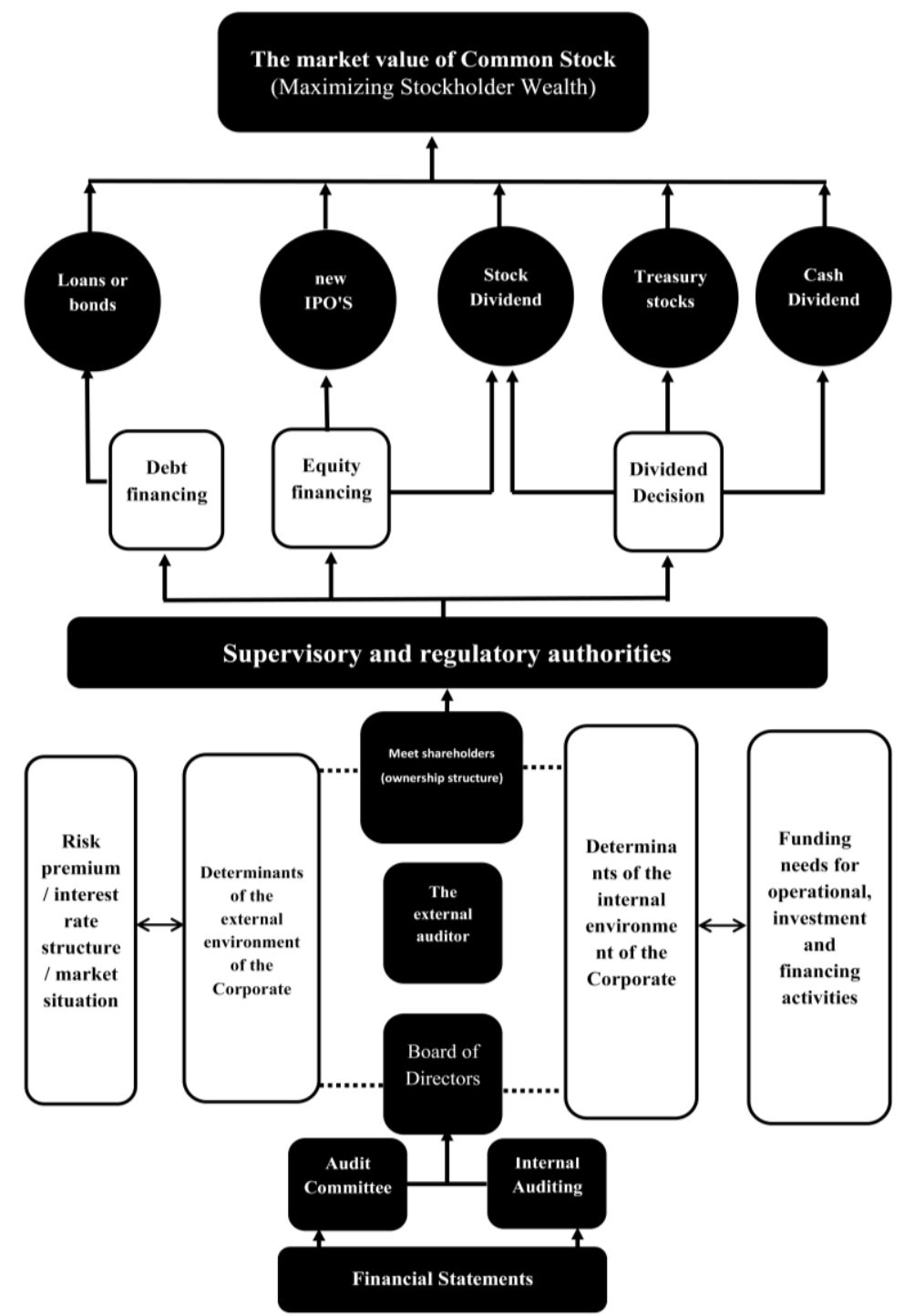

Figure 3. Dividend decision under corporate governance mechanisms to maximizing stockholder wealth Source: Authors.

Therefore, it is up to the board of directors to present to the General Assembly, which represents the fifth mechanism of governance mechanisms. It is the ownership structure that discusses the financial performance of the Corporate in addition to studying the recommendations of the Board of Directors in general and towards the decision to distribute profits, especially in the case of distributing free shares (increasing the paid capital Through transfers from retained earnings and reserves) which require a decision from the Extraordinary General Assembly, the supervisory and regulatory authorities are responsible for determining the extent to which the legal requirements are met to ensure the rights of the minority and achieve fairness between all classes of 
shareholders and the rest of the stakeholders.

Internal audit is considered as one of the components of the internal control system. Business establishments in the United States of America have become required to report on their internal control activities, in addition to financial reports to achieve compliance with the requirements of Section 404 of the Sarbanes-Oxley Law, and thus the ineffective performance of the internal audit function is seen by the entity's external auditor as an indication of deficiencies or weaknesses in the entity's internal control systems, which affects the enhancement of risk management performance. (Ge \& McVay, 2005; Abbott et al., 2007; Hoitash et al., 2008; Hammersley et al., 2008) where the main role of internal audit in consideration of governance mechanisms is to ensure that professional requirements are followed for recognition, measurement, and disclosure of its assets and liabilities towards third parties in order to fairly determine shareholders' rights.

In addition, the internal auditing processes and the associated procedures for evaluating the operating performance of the corporate by analyzing profitability centers in conjunction with the rest of the relevant internal parties, which gives financial and non-financial indicators of the efficiency of the assets under the control of management by determining the internal rate of return. For those assets, instead of determining the level of idle energies in consideration of the available production capabilities as well as studying the bottlenecks of production capacity, and finally identifying untapped assets and what follows that in preparing improvement and development plans to improve the financial performance of the facility with the rest of the relevant internal parties for presentation and discussion by the Board of Directors under the comparison between the internal rate of return and the arbitrage cost of capital.

The accounting and auditing profession at the beginning of the second millennium witnessed financial crises and scandals initiated by the company (Enron), as it used what is known as the term special purpose units in order to reach the money market and protect itself from risks. This made (Enron) bear greater obligations to issue additional shares which caused a decrease in the value of the company's shares and at the end of 2001 the company disclosed losses in the third quarter, and as a result, the value of the share decreased significantly. This was followed by a series of financial failures and failure of auditing processes, as it included many establishments, including (Health South), (World Com) and (Tyco), and as a result, attention was paid to corporate governance and the emergence of the Oxley Act in 2002 in the United States of America.

However, the reality of companies' failure continued after that through what the establishments were exposed to. They did not disclose the size of the risks they were exposed to which was clearly evident in 2008 in regards of the mortgage crisis which led to the collapse of many American banks and financial institutions, including Lehman Brothers. Despite the passage of 6 years since the issuance of the Oxley Act, which means the importance of an independent oversight authority over internal audit work, this is the role that the audit committee plays by ensuring the discipline of measurement processes and recognition of all assets and liabilities of the facility.

Thus, it appears that the audit committee represents the second control circle on management practices, whose effectiveness is linked to each of the independence of its members, the periodicity of its meetings and the efficiency of its practices, which guides the decisions of the establishment as these decisions are based on data and information that reflects the reality of the financial performance of the facility, which includes with every decision to distribute profits.

Regarding the results of the conducted studies, (Nimer et al., 2012) indicated that there is no relationship between the effectiveness of the external audit committee and the dividend decision in the Jordanian industrial companies. This is rather than using the survey list method to assess the effectiveness of audit committees, as we find on the other hand the results of a study indicating a relationship between the effectiveness of the external audit committee and the dividend decision in Egyptian industrial companies.

The board of directors plays the first game in the stock market. This is because it has the ability to access data and information about the established performance, whether financial or non-financial, in advance from the rest of the stakeholders therefore it sends many signals to the parties of the market.

Therefore, it is essential for the board of directors to realize the determinants of the dividend policy and their implications for the cash flow in the facility and its ability to grow and expand, and the resulting re-evaluation of the decision (dividend decision) in consideration of the preferences and trends of shareholders towards the relationship between real returns (rate of return on assets) ROA, the rate of return on equity (ROE) and financial (current Yield), the rate of return of the holding period (on the one hand, the risks associated with that howl in real terms) measured using both financial and macro leverage (and financial) measured using the standard deviation of returns- systematic risk factor $\beta$ ). 
According to the results of the studies, many authors have referred to the role of the board of directors and its characteristics in the decision to distribute profits, whether in developed or emerging markets, and among those studies (Leng, 2007) (Al-Najjar \& Hussainey, 2009) (Adjaoud \& Be-Amar, 2010), (Jiraporn et al., 2011), (Subramaniam \& Devis, 2011)

In a rare study that dealt with the Korean corporate governance law issued in 1999, the study (Black \& Kim, 2012) concluded that restructuring the board of directors by increasing independent board members to $50 \%$ according to the Korean Governance Law positively affects the market value and the company's performance in Emerging markets. The study also found that the market value of large-sized companies increased compared to medium-sized companies when they followed the law issued in 1999.

The Corporate is seen as continuing its business in the long term, therefore it is the responsibility of the auditor to determine the entity's ability to continue in accordance with local standards (Auditing Standard No. 570: Continuity, Auditing Standard No. 200: The objective of the financial statement review process and the general principles that in light of this, the auditor's report represents the last stage in the review process, and the process of collecting and evaluating evidence is only carried out for the purpose of expressing the opinion of the auditor, and this professional opinion is the main goal of those processes, and the professional opinion cannot be expressed unless after the auditor assesses the risks of the audit process and completes all the audit tests. Reports prepared by the auditor can be classified into one of the cases clean opinion, conservative opinion, opposite (negative) opinion, or abstaining from expressing opinion.

The researchers find that the deficiencies in the financial reports are the limitations facing the auditor in assessing the viability of the enterprise, and perhaps one of the most important deficiencies includes the failure of the current financial reports to respond to the requirements of the new economy, with regard to intellectual capital, intellectual property and patents, the adoption of current financial reports mainly on cost. Historical or mixed cost, inability of current financial reports to provide users' needs of non-financial information related to operation and performance measures, failure to provide information related to the systemic risks facing the enterprise, lack of future information (information related to opportunities and risks - information related to future management plans), Focusing current financial reports on providing information related to the facility only, not providing information that honestly expresses the reality of financial instruments and the financial risks related to them and methods of hedging these risks.

Therefore, the researchers point out that the external auditor should familiarize themselves with each of the business models, business risks, and determine the impact of the dividend decision in its various patterns on the entity's ability to continue in general along with indicating the sources of cash distributions if they are operational flows or not. If they are not of operational flows, he must refer to this in his report, given the unconventional risks this situation carries for interest groups, especially shareholders and creditors.

Regarding the results of the studies, there is a study that indicates that there is a reflection of the quality of auditing processes as measured by the audit fees, the size of the audit office and the link with international offices for auditing and the professional qualification of the auditor on the cash distributions of Egyptian companies in light of the quality of profits.

The announcement views dividend in its various types as a channel of communication between the board of directors and the stock market, and where the board of directors works to maximize the internal return, which can be measured through the "rate of return on assets (ROA") and "the rate of return on the right of ownership (ROE"), where the dividend decision is one of the financial signals issued by the entity to the market, which requires a fair and rational reassessment of changes in the investment structure of the enterprise and its financing structure by supplying the financial market with relevant information. Stream benefits for shareholders at the same time.

The results of previous studies refer widely to the effect of the ownership structure on the dividend decision, which is evident in the institutional ownership pattern (Grinstein \& Michaely, 2005) and the family ownership pattern (Isakov \& Weisskopf, 2015).

\section{Data Analysis and Hypotheses Testing}

\subsection{Corporate Governance at Egypt}

In October 2005 the Ministry of Investment issued the first local rules for governance, or what was known at the time, the first Egyptian Governance Code by issuing a guide to corporate governance for companies listed on the Egyptian Stock Exchange, EGX. The guide represents the general framework for the principles of Egyptian corporate governance. It included an important set of rules that would increase the effectiveness of boards of 
directors, and ensure the rights of shareholders and dealers with listed companies. This was followed by many issues, such as the issuance of the second corporate governance code in July 2006 issued by the Managers Center of the Ministry of Investment and then the second Egyptian Governance Code in March 2011 issued by the same center.

Today, the Egyptian Stock Exchange is implementing the third code issued by the Affiliated Directors Center that became affiliated with the General Authority for Non-Banking Financial Supervision in August 2016, as the rules of Egyptian governance were incorporated into the rules for listing and delisting securities on the Egyptian Stock Exchange, in Chapter Four of the rules issued by the General Authority's decision Financial Control No. 11 on January 22, 2014, but the researchers find severe deficiencies in this merging, which was limited to the procedural aspect of some practices such as general assemblies or issuance of documents such as the report of the Board of Directors, without reference to the basis for determining the rights of stakeholders.

\subsection{Quantitative Analysis}

\subsubsection{Data Collection for Quantitative Analysis}

The study relied on the data of the financial companies listed in the Egyptian Stock Exchange during the period 2010 to 2019 by relying on documentary surveys of the periodic reports of the S \& P-EGX-ESG index, which evaluates the 100 most active companies listed on the Egypt 100 Index (EGX100); through what it made available, directly or indirectly, as follows:
a. Board of Directors' report
b. Board of Directors decisions
c. Auditor's report
d. Record of the Ordinary and Extraordinary General Assembly meetings
e. Record of the audit committee meeting
f. Material disclosures and announcements
g. Disclosure
h. Reports and publications of the Ministry of Environment.

\subsubsection{The Study Sample for Quantitative Analysis}

The study adopted the S\&P/ EGX ESG index, an index that was issued via the Egyptian Stock Exchange in cooperation with the Egyptian Center of Directors and Standard \& Poor's Corporation, where the arbitrary sample method was used through a comprehensive inventory of companies listed on the index that index, and have been registered in the Egyptian Stock Exchange since the year 2007. The following table shows the study sample for quantitative analysis.

Table 8 . The study sample for quantitative analysis

\begin{tabular}{ccc}
\hline No & Companies Name & Reuters code \\
\hline 1 & Abu Dhabi Islamic Bank-Egypt & ADIB.CA \\
2 & Baraka Bank-Egypt & SAUD.CA \\
3 & Commercial International Bank & COMI.CA \\
4 & Credit Agricole Egypt Bank & CIEB.CA \\
5 & Egyptian iron and steel & IRON.CA \\
6 & Egyptian Kuwaiti Holding & EKHO.CA \\
7 & Egyptian Transport Services (Egytrans) & ETRS.CA \\
8 & EFG Hermes Holding & HRHO.CA \\
9 & Nasr City for Housing and Development & MNHD.CA \\
10 & Oriental Weavers & ORWE.CA \\
11 & Paints and Chemical Industries - Pachin & PACH.CA \\
12 & Palm Hills Development & PHDC.CA \\
13 & Raya Holding for Financial Investments & RAYA.CA \\
14 & Sidi Kerir Petrochemical & SKPC.CA \\
15 & Six of October Development \& Investment (SODIC) & OCDI.CA \\
\hline
\end{tabular}


4.2.3 Examining the Impact of the Governance Mechanisms on Achieving the Goal of Maximizing Stockholder Wealth

The study relied on the state of return in determining the state of maximizing the wealth of the stockholders, in consideration of the practices of governance mechanisms, by applying Panel data (cross-sectional units) method, and the outputs of the analysis were as Figure 4.

Through the Panel data model, Adjusted R-squared estimated at (60.97\%), which indicates the quality of the model description ratio, which indicates the quality of the model in expressing the effect of independent variables that is governance mechanisms on the dependent variable maximizing stockholder wealth according to increase at the market value of common stock.

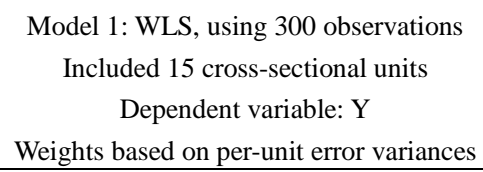

Weights based on per-unit error variances

\begin{tabular}{|c|c|c|c|c|c|}
\hline & Coefficient & Std. Error & $t$-ratio & $p$-value & \\
\hline const & 0.817703 & 0.0359107 & 22.77 & $<0.0001$ & $* * *$ \\
\hline $\mathrm{BD}$ & -0.822999 & 0.0555975 & -14.80 & $<0.0001$ & $* * *$ \\
\hline $\mathrm{AC}$ & 0.746412 & 0.0560320 & 13.32 & $<0.0001$ & $* * *$ \\
\hline IA & 0.117367 & 0.0561159 & 2.092 & 0.0373 & $* *$ \\
\hline EA & 0.0116050 & 0.0435176 & 0.2667 & 0.7899 & \\
\hline OS & 0.0812209 & 0.0390409 & 2.080 & 0.0384 & $* *$ \\
\hline $\mathrm{SC}$ & 0.0730729 & 0.0555436 & 1.316 & 0.1893 & \\
\hline \multicolumn{6}{|c|}{ Statistics based on the weighted data: } \\
\hline Sum squared resid & \multicolumn{2}{|c|}{283.7765} & S.E. of regression & & 0.984134 \\
\hline R-squared & \multicolumn{2}{|c|}{0.617585} & Adjusted R-squared & & 0.609754 \\
\hline $\mathrm{F}(6,293)$ & \multicolumn{2}{|c|}{78.86378} & P-value(F) & & $2.92 \mathrm{e}-58$ \\
\hline Log-likelihood & \multicolumn{2}{|c|}{-417.3422} & Akaike criterion & & 848.6844 \\
\hline Schwarz criterion & \multicolumn{2}{|c|}{874.6109} & Hannan-Quinn & & 859.0602 \\
\hline \multicolumn{6}{|c|}{ Statistics based on the original data: } \\
\hline Mean dependent var & \multicolumn{2}{|c|}{0.550000} & S.D. dependent var & & 0.498325 \\
\hline Sum squared resid & \multicolumn{2}{|c|}{42.26025} & sion & & 0.379780 \\
\hline
\end{tabular}

Figure 4. Outputs of inferential statistical for (H1)

Source: the Gnu Regression, Econometrics and Time-series Library.

According to inferential statistical; the governance mechanisms that impact on stockholder wealth ' wealth are:
a. The Board of Directors
b. The Audit Committee
c. The Audit Committee
d. The Ownership Structure

\subsection{Qualitative Analysis}

\subsubsection{Data Collection for Qualitative Analysis}

The study relied on the method of measuring attitudes according to surveyed were included as follows:
a. Member of the Board of Directors
b. Executive Director
c. Investor or trader in the Egyptian Stock Exchange
d. External auditor
e. Internal auditor
f. Financial Analyst / Financial Adviser
g. Portfolio Manager
h. A credit manager in a financial institution 
The table 9 illustrates the response rates and the completed lists, while the figure 5 illustrates the weights of sample.

Table 9. Survey collection

\begin{tabular}{rccccc}
\hline & Distributed survey lists & Un-received Survey lists & Received Survey lists & Incomplete survey lists & Completed survey lists \\
\hline No. & 517 & 45 & 472 & 55 & 417 \\
$\%$ & $100 \%$ & $8.71 \%$ & $91.29 \%$ & $10.63 \%$ & $80.65 \%$ \\
\hline
\end{tabular}

Source: prepared by the researchers based on the processes of distributing and emptying the survey lists.

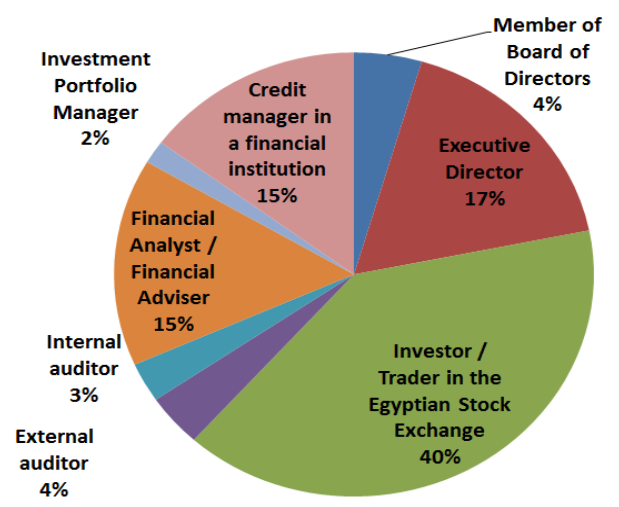

Figure 5. Sample characteristics of qualitative analysis

Source: prepared by the researchers based on the operations of unpacking the survey lists.

4.2.2 Examining the impact of Board of Directors on dividend decision (H2)

Table 10. Outputs of inferential statistical for (H2)

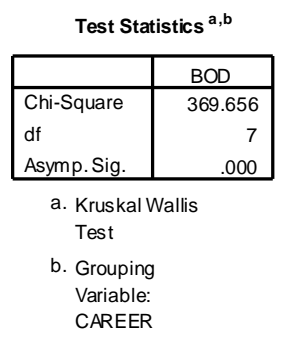

Source: Statistical Package for the Social Sciences (SPSS).

Through the previous statistical analysis, the study observes that the value of $\left(\mathrm{Chi}^{2}\right)$ was $(369,656)$ at degrees of freedom (7) is significant at the level of (1\%). Thus, it is possible to reject the null hypothesis and accept the alternative hypothesis: "there is a significant difference in the attitudes of stakeholders towards the role of the Board of Directors in determining of dividend decision.

4.2.3 Examining the impact of Shareholders Structure on Dividend Decision (H3)

Table 11. Outputs of inferential statistical for (H3)

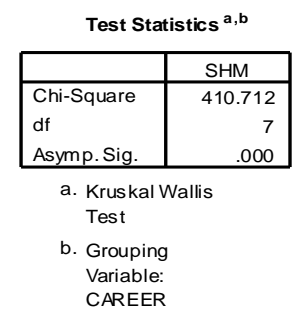

Source: Statistical Package for the Social Sciences (SPSS). 
Through the previous statistical analysis, the study observes that the value of $\left(\mathrm{Chi}^{2}\right)$ was $(410,712)$ at degrees of freedom (7) is significant at the level of (1\%). Thus, it is possible to reject the null hypothesis and accept the alternative hypothesis: "There is a significant difference in the attitudes of stakeholders towards the role of a Shareholder's Structure in determining the pattern of dividend decision".

4.2.4 Examining the Impact of Internal Audit on Dividend Decision (H4)

Table 12. Outputs of inferential statistical for (H4)

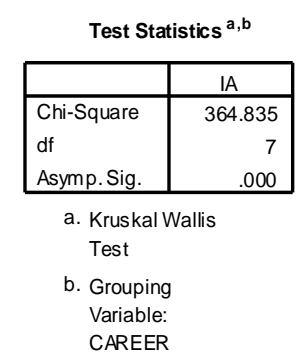

Source: Statistical Package for the Social Sciences (SPSS).

Through the previous statistical analysis, the study observes that the value of $\left(\mathrm{Chi}^{2}\right)$ was $(364,835)$ at degrees of freedom (7) is significant at the level of (1\%). Thus, it is possible to reject the null hypothesis and accept the alternative hypothesis: "There is a significant difference in the attitudes of stakeholders towards the internal audit role in determination of dividend decision".

4.2.5 Examining the Impact of Audit Committee on Dividend Decision (H5)

Table 13. Outputs of inferential statistical for (H5)

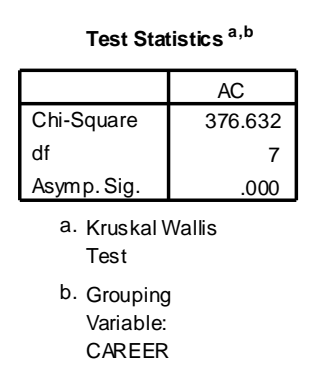

Source: Statistical Package for the Social Sciences (SPSS).

Through the previous statistical analysis, the study observes that the value of $\left(\mathrm{Chi}^{2}\right)$ was $(376,632)$ at degrees of freedom (7) is significant at the level of (1\%). Thus, it is possible to reject the null hypothesis and accept the alternative hypothesis: "There is a significant difference in the attitudes of stakeholders towards the role of an audit committee in determining of dividend decision".

4.2.6 Examining the impact of external audit on dividend decision (H6)

Table 14. Outputs of inferential statistical for (H6)

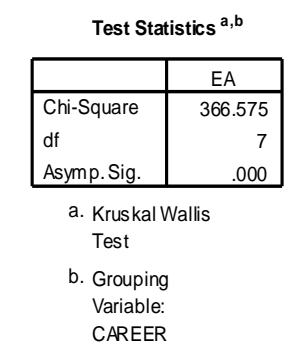

Source: Statistical Package for the Social Sciences (SPSS). 
Through the previous statistical analysis, the study observes that the value of $\left(\mathrm{Chi}^{2}\right)$ was $(366,575)$ at degrees of freedom (7) is significant at the level of $(1 \%)$. Thus, it is possible to reject the null hypothesis and accept the alternative hypothesis: "There is a significant difference in the attitudes of stakeholders towards the External audit role in determining of dividend decision".

4.2.6 Examining the impact of Regulatory and supervisory authorities on dividend decision (H7)

Table 15. Outputs of inferential statistical for (H7)

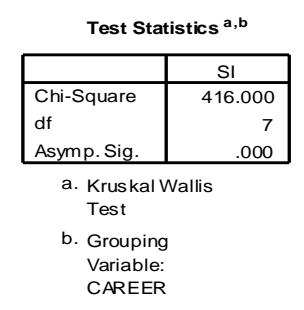

Source: Statistical Package for the Social Sciences (SPSS).

Through the previous statistical analysis, the study observes that the value of $\left(\mathrm{Chi}^{2}\right)$ calculated at (416) at degrees of freedom (7) is significant at the level of (1\%). Thus, it is possible to reject the null hypothesis and accept the alternative hypothesis: "there is a significant difference in the attitudes of stakeholders towards the role of the Regulatory and supervisory authorities in determining of dividend decision".

From the foregoing, the null hypothesis is rejected and the alternative hypothesis is accepted: "There is a significant difference in the attitudes of stakeholders towards the role of governance mechanisms to determine of dividend decision."

\section{Conclusions and Recommendations}

\subsection{Conclusions}

1) The lack of realism of the goal of Maximizing stockholder wealth is the reason for generating the agency problem, resulting from managers' detachment from this goal, maximizing the wealth of stockholder according to the disparity of interests and informational asymmetry between managers and shareholders, which is what gives up the problem of management's avoidance of risk, the problem of the increasing retention of profits, and the over retention problem. Thus, there are several deficiencies that financial markets suffer from in relation to the dividend decision.

2) Corporate Governance (CG) is not an end in itself, as it seeks to improve the performance of corporate in the business environment in which they operate, while working to target maximizing the stockholder wealth in consideration of the rights of any of the other stakeholders through the connection with the minimal level of conflict of interests.

3) There is a conflict between two ideological trends; the first is Medicliani and Modigliani \& Miller, who believes that the dividend decision does not affect the value of the enterprise versus the second trend, which includes many theories that seek to provide explanations for the dividend of profits including; the surplus dividend theory, the theory of tax impact, the sign theory. The researchers find that the second trend is the most realistic in consideration of the standard evaluation models (such as the Gordon model for discounted cash distributions - the discounted free cash flow model) or behavioral finance theories (such as the utility theory).

4) There is a set of determinants that affect the dividend decision to include the size and pattern of this distribution, and those determinants can be classified into two groups; the first set of determinants is related to the agency problem and include: homogeneity of ownership, size of the establishment, levels of risk, cost structure, growth stage in the life cycle. The other set of determinants is not related to the agency problem include levels of liquidity, sector type, and legal considerations.

5) There is an integration between the roles of CGM in rationalizing the dividend decision, as CGM start their role from the internal audit mechanism and then the audit committee, and its main role is to ensure that the measurement and recognition processes are completed in accordance with the relevant professional principles (Egyptian Accounting Standards) and international accounting standards according to the 
circumstances) where the financial statements are prepared, followed by reports that must fairly reflect the reality of the entity's financial performance, including in this regard the relevant financial or non-financial information. The board of directors is the third mechanism that deals with the reality of the entity's financial performance; which in turn resolves the financial statements to external auditing processes and thus shows the role of the external auditor as a fourth mechanism of government mechanisms, which is concerned with expressing professional opinion on the extent of fairness and clarity of financial statements, and finally we find a mechanism of supervisory and regulatory bodies that seek to protect the rights of shareholders, especially the rights of the minority and therefore all governance mechanisms are clear.

6) The Egyptian Exchange's adoption of the principles of governance is not new, but there is a weakness in many efficient practices (Wagdi, 2013).

7) According to the quantitative analysis, the interpretation rate of corporate governance mechanisms is $60.97 \%$ of the maximizing stockholder wealth in the Egyptian business environment. According to inferential statistical; the governance mechanisms that impact on stockholder wealth " wealth are "board of directors"; "audit committee"; "audit committee" and "ownership structure".

8) According to the qualitative analysis there is a difference in the attitudes of stakeholders towards the role of governance mechanisms to determine of dividend decision.

\subsection{Recommendations}

1) Developing the rules for listing and delisting securities on the Egyptian Stock Exchange issued by the Financial Supervisory Authority Resolution No. 11 on January 22, 2014, especially Chapter Four of more legal requirements to support effective practices and governance mechanisms.

2) Increasing the awareness of executive managers; especially members of senior management in companies listed on stock exchanges, of the importance of the dividend decision, as it has direct and indirect repercussions on the value of the issuing enterprise, and this can be achieved through holding workshops. We suggest that the Egyptian Directors Center organize them or the Non-Banking Financial Supervisory Authority, in addition to professional societies such as the Egyptian Securities Association.

3) The development of disclosure rules, whereby the listed companies must be required to disclose the justifications for the dividend decision (Retained Earnings - cash dividend - stock dividend- purchase of treasury stock), as this has an impact on supporting the level of information efficiency in the Egyptian Stock Exchange.

4) Working to support the integration of governance mechanisms, by increasing the level of communication and cooperation between the board of directors, the general assembly, the internal audit, the audit committee, the external audit, and the shareholders, the supervisory authorities through the effective exchange of data, information and reports to reduce the lack of coordination between them.

5) The following topic may be a potential future study: A comparative analysis of the Corporate Governance on Dividend Decision to Maximizing Stockholder Wealth: A cross-sectional analysis.

\section{References}

Abbott, L. J., Parker, S., Peters, G. F., \& Rama, D. V. (2007). Corporate governance, audit quality, and the Sarbanes-Oxley Act: Evidence from internal audit outsourcing. The Accounting Review, 82(4), 803-835. https://doi.org/10.2308/accr.2007.82.4.803

Adjaoud, F., \& Ben-Amar, W. (2010). Corporate governance and dividend policy: Shareholders' protection or expropriation? Journal of Business Finance \& Accounting, 37(5-6), 648-667. https://doi.org/10.1111/j.1468-5957.2010.02192.x

Aktas, N., de Bodt, E., \& Cousin, J. G. (2007). Event studies with a contaminated estimation period. Journal of Corporate Finance, 13(1), 129-145. https://doi.org/10.1016/j.jcorpfin.2006.09.001

Al-Najjar, B., \& Hussainey, K. (2009). The association between dividend payout and outside directorships. Journal of Applied Accounting Research, 10(1), 4-19. https://doi.org/10.1108/09675420910963360

Anderson, C. W., \& Campbell II, T. L. (2004). Corporate governance of Japanese banks. Journal of Corporate Finance, 10(3), 327-354. https://doi.org/10.1016/S0929-1199(03)00029-4

Ayuso, S., Rodríguez, M. A., García-Castro, R., \& Ariño, M. A. (2014). Maximizing stakeholders' interests: An empirical analysis of the stakeholder approach to corporate governance. Business \& Society, 53(3), 414-439. https://doi.org/10.1177/0007650311433122 
Baker, H. K., \& De Ridder, A. (2018). Payout policy in industrial and financial firms. Global Finance Journal, 37, 138-151. https://doi.org/10.1016/j.gfj.2018.05.005

Ball, C. A., \& Torous, W. N. (1988). Investigating security-price performance in the presence of event-date $\begin{array}{lllll}\text { uncertainty. Journal of } & \text { Financial }\end{array}$ https://doi.org/10.1016/0304-405X(88)90025-6

Bellovary, J. L., Giacomino, D. E., \& Akers, M. D. (2005). Earnings quality: It's time to measure and report. The CPA Journal, 75(11), 32-37. Retrieved from https://core.ac.uk/download/pdf/67756541.pdf

Berry, M. A., Gallinger, G. W., \& Henderson Jr, G. V. (1990). Using daily stock returns in event studies and the choice of parametric versus nonparametric test statistics. Quarterly Journal of Business and Economics, 70-85. Retrieved from https://www.jstor.org/stable/40472983

Binder, J. J. (1985). On the use of the multivariate regression model in event studies. Journal of Accounting Research, 370-383. https://doi.org/10.2307/2490925

Boehmer, E., Masumeci, J., \& Poulsen, A. B. (1991). Event-study methodology under conditions of event-induced variance. Journal of Financial Economics, 30(2), 253-272. https://doi.org/10.1016/0304-405X(91)90032-F

Burlaka, M. V. (2005). Bank corporate governance: The emerging Ukrainian market compared to international best practices. Fordham Journal of Corporate \& Financial Law, 11(4), 851-891. Retrieved from https://heinonline.org/HOL/LandingPage?handle=hein.journals/fjcf11\&div=40\&id=\&page=

Chen, C. X., Lu, H., \& Sougiannis, T. (2012). The agency problem, corporate governance, and the asymmetrical behavior of selling, general, and administrative costs. Contemporary Accounting Research, 29(1), 252-282. https://doi.org/10.1111/j.1911-3846.2011.01094.x

Code, C. (1992). Report of the committee on the financial aspects of corporate governance: The code of best practice. Retrieved from http://hdl.handle.net/10068/390722

Corrado, C. J. (1989). A nonparametric test for abnormal security-price performance in event studies. Journal of Financial Economics, 23(2), 385-395. https://doi.org/10.1016/0304-405X(89)90064-0

Corrado, C. J. (2011). Event studies: A methodology review. Accounting \& Finance, 51(1), 207-234. https://doi.org/10.1111/j.1467-629X.2010.00375.x

De Miguel, A., Pindado, J., \& De la Torre, C. (2004). Ownership structure and performance: A comparison of different corporate governance systems. Journal of Corporate Ownership \& Control, 2(4), 76-85. https://doi.org/10.22495/cocv2i4p7

Dehghani, P., \& Chun, L. S. (2011). The impact of the special dividend announcement on the stock return: The case of Malaysia. Journal of International Business Research, 10(1), 77-95. Retrieved from https://www.researchgate.net/profile/Pegah_Dehghani/publication/228119428_The_Impact_of_the_Special _Dividend_Announcement_on_the_Stock_Return_The_Case_of_Malaysia/links/0c96052f8ab84072fe0000 00/The-Impact-of-the-Special-Dividend-Announcement-on-the-Stock-Return-The-Case-of-Malaysia.pdf\#pa ge $=83$

Demb, A., \& Neubauer, F. F. (1992). The corporate board: Confronting the paradoxes. Oxford University Press on Demand. https://doi.org/10.1016/0024-6301(92)90364-8

Dempsey, M., Gunasekarage, A., \& Truong, T. T. (2019). The association between dividend payout and firm growth: Australian evidence. Accounting \& Finance, 59(4), 2345-2376. https://doi.org/10.1111/acfi.12361

Eckbo, B. E., Maksimovic, V., \& Williams, J. (1990). Consistent estimation of cross-sectional models in event studies. The Review of Financial Studies, 3(3), 343-365. https://doi.org/10.1093/rfs/3.3.343

Eisenhardt, K. M. (1989). Agency theory: An assessment and review. Academy of Management Review, 14(1), 57-74. https://doi.org/10.5465/amr.1989.4279003

Elmagrhi, M. H., Ntim, C. G., Crossley, R. M., Malagila, J. K., Fosu, S., \& Vu, T. V. (2017). Corporate governance and dividend pay-out policy in UK listed SMEs: The effects of corporate board characteristics. International Journal of Accounting \& Information Management, 25(4), 459-483. https://doi.org/10.1108/IJAIM-02-2017-0020

Farinha, J. (2003). Dividend policy, corporate governance and the managerial entrenchment hypothesis: an empirical analysis. Journal of Business Finance \& Accounting, 30(9-10), 1173-1209. 
https://doi.org/10.1111/j.0306-686X.2003.05624.x

Fawzy, S. (2003). Assessment of corporate governance in Egypt. The Egyptian Centre for Economic Studies Working Paper, 82. Retrieved from http://www.eiod.org/uploads/publications/pdf/assessingcgegypt.pdf

Ge, W., \& McVay, S. (2005). The disclosure of material weaknesses in internal control after the Sarbanes-Oxley Act. Accounting Horizons, 19(3), 137-158. https://doi.org/10.2308/acch.2005.19.3.137

Grinblatt, M. S., Masulis, R. W., \& Titman, S. (1984). The valuation effects of stock splits and stock dividends. Journal of Financial Economics, 13(4), 461-490. https://doi.org/10.1016/0304-405X(84)90011-4

Grinstein, Y., \& Michaely, R. (2005). Institutional holdings and payout policy. The Journal of Finance, 60(3), 1389-1426. https://doi.org/10.1111/j.1540-6261.2005.00765.x

Gugler, K. (2003). Corporate governance, dividend payout policy, and the interrelation between dividends, R\&D, and capital investment. Journal of Banking \& Finance, 27(7), 1297-1321. https://doi.org/10.1016/S0378-4266(02)00258-3

Hammersley, J. S., Myers, L. A., \& Shakespeare, C. (2008). Market reactions to the disclosure of internal control weaknesses and to the characteristics of those weaknesses under section 302 of the Sarbanes Oxley Act of 2002. Review of Accounting Studies, 13(1), 141-165. https://doi.org/10.1007/s11142-007-9046-Z

Hart, O. (1995). Corporate governance: Some theory and implications. The Economic Journal, 105(430), 678-689. https://doi.org/10.2307/2235027

Henderson Jr, G. V. (1990). Problems and solutions in conducting event studies. Journal of Risk and Insurance, 282-306. https://doi.org/10.2307/253304

Hoitash, R., Hoitash, U., \& Bedard, J. C. (2008). Internal control quality and audit pricing under the Sarbanes-Oxley Act. Auditing: A Journal of Practice \& Theory, 27(1), 105-126. https://doi.org/10.2308/aud.2008.27.1.105

Isakov, D., \& Weisskopf, J. P. (2015). Pay-out policies in founding family firms. Journal of Corporate Finance, 33, 330-344. https://doi.org/10.1016/j.jcorpfin.2015.01.003

Jiraporn, P., Kim, J. C., \& Kim, Y. S. (2011). Dividend payouts and corporate governance quality: An empirical investigation. Financial Review, 46(2), 251-279. https://doi.org/10.1111/j.1540-6288.2011.00299.x

Kambil, A., Long, V. W. T., \& Kwan, C. (2006). The seven disciplines for venturing in China. MIT Sloan Management Review, 47(2), 85. http://library.cust.edu.pk/MIT/2006/Winter2006/47217SxW.pdf

Kim, J. Y., \& Ettredge, M. (1992). LIFO adoption and dividend payout. Managerial and Decision Economics, 13(6), 475-484. https://doi.org/10.1002/mde.4090130603

Kolari, J. W., \& Pynnonen, S. (2011). Nonparametric rank tests for event studies. Journal of Empirical Finance, 18(5), 953-971. https://doi.org/10.1016/j.jempfin.2011.08.003

Kothari, s. (2004).Stock returns aggregate earnings surprises, and behavioral finance. Working Paper No. 4284-03; SIMON school of business working paper No. FR 03-05. https://doi.org/10.1016/j.jfineco.2004.06.016

Kulchania, M. (2016). Cost structure and payout policy. Financial Management, 45(4), 981-1009. https://doi.org/10.1111/fima.12133

Kyereboah-Coleman, A., \& Biekpe, N. (2006). The relationship between board size, board composition, CEO duality and firm performance: Experience from Ghana. Corporate Ownership and Control, 4(2), 114-122. https://doi.org/10.22495/cocv4i2p11

Leng, C. A. (2007). The impact of internal and external monitoring measures on firm's dividend payout: Evidence from selected Malaysian public listed companies. International Journal of Business and Management, 2(5), 31-45. http://citeseerx.ist.psu.edu/viewdoc/download?doi=10.1.1.123.8970\&rep=rep1\&type=pdf\#page=32

Mehdi, M., Sahut, J. M., \& Teulon, F. (2017). Do corporate governance and ownership structure impact dividend policy in emerging market during financial crisis? Journal of Applied Accounting Research, 18(3), 274-297. https://doi.org/10.1108/JAAR-07-2014-0079

Mitton, T. (2004). Corporate governance and dividend policy in emerging markets. Emerging Markets Review, 5(4), 409-426. https://doi.org/10.1016/j.ememar.2004.05.003 
Nimer, K. M., Warrad, L., \& Khuraisat, O. (2012). The effect of audit committee's effectiveness on dividend payout policy: Evidence from the Jordanian firms. International Journal of Business and Management, 7(7), 172-179. https://doi.org/10.5539/ijbm.v7n7p172

OECD, O. (2004). The OECD principles of corporate governance. Organization for Economic Cooperation \& Development. https://doi.org/10.22201/fca.24488410e.2005.562

Polsiri, P., \& Wiwattanakantang, Y. (2006). Corporate Governance of Banks in Thailand. Working Paper Series, $\begin{array}{lllll}\text { Center for } & \text { Economic Institutions. } & \text { Retrieved }\end{array}$ http://hermes-ir.lib.hit-u.ac.jp/hermes/ir/re/13500/wp2005-20a.pdf

Rozeff, M. S. (1982). Growth, beta and agency costs as determinants of dividend payout ratios. Journal of Financial Research, 5(3), 249-259. https://doi.org/10.1111/j.1475-6803.1982.tb00299.x

Salinger, M. (1992). Standard errors in event studies. Journal of Financial and Quantitative Analysis, 27(1), 39-53. https://doi.org/10.2307/2331297

Savickas, R. (2003). Event-Induced Volatility and Tests for Abnormal Performance. Journal of Financial Research, 26(2), 165-178. https://doi.org/10.1111/1475-6803.00052

Seal, W. (2006). Management accounting and corporate governance: An institutional interpretation of the agency problem. Management Accounting Research, 17(4), 389-408. https://doi.org/10.1016/j.mar.2006.05.001

Seiler, M. J. (2000). The efficacy of event study methodologies: Measuring EREIT abnormal performance under conditions of induced variance. Journal of Financial and Strategic Decisions, 13(1), 101-112. http://www.financialdecisionsonline.org/archive/pdffiles/v13n1/seiler.pdf

Shleifer, A., \& Vishny, R. W. (1997). A survey of corporate governance. Journal of Finance, 52(2), 737-783. https://doi.org/10.1111/j.1540-6261.1997.tb04820.x

Spivey, S. (2004). Corporate governance and the role of government. International Journal of Disclosure and Governance, 1(4), 307-312. https://doi.org/10.1057/palgrave.jdg.2040032

Subramaniam, R., \& Devi, S. S. (2011). Corporate governance and dividend policy in Malaysia. International Conference on Business Economics Research, Kuala Lumpur, Malaysia. Retrieved from http://www.ipedr.com/vol1/44-B10051.pdf

Van den Berghe, L. A., \& Levrau, A. (2004). Evaluating boards of directors: What constitutes a good corporate board?. Corporate Governance: An International Review, 12(4), 461-478. https://doi.org/10.1111/j.1467-8683.2004.00387.x

Vandemaele, S., \& Vancauteren, M. (2015). Nonfinancial goals, governance, and dividend payout in private family firms. Journal of Small Business Management, 53(1), 166-182. https://doi.org/10.1111/jsbm.12063

Wagdi, O. (2013). Corporate Governance: Egyptian Exchange Case. Institutions \& Transition Economics: Firm Governance eJournal, 5(29). https://dx.doi.org/10.2139/ssrn.2349738

Walker, R. G. (2004). Gaps in guidelines on audit committees. Abacus, 40(2), 157-192. https://doi.org/10.1111/j.1467-6281.2004.00156.x

Wu, M. C., Kao, E. H., \& Fung, H. G. (2008). Impact of dividend-protected employee stock options on payout policies: Evidence from Taiwan. Pacific Economic Review, 13(4), 431-452. https://doi.org/10.1111/j.1468-0106.2008.00411.x

Zeng, T. (2011). Intercorporate ownership, taxes, and corporate payout choices. Accounting Perspectives, 10(4), 265-283. https://doi.org/10.1111/j.1911-3838.2011.00027.x

\section{Copyrights}

Copyright for this article is retained by the author(s), with first publication rights granted to the journal.

This is an open-access article distributed under the terms and conditions of the Creative Commons Attribution license (http://creativecommons.org/licenses/by/4.0/). 